\title{
Article
}

\section{The crystal structure of alstonite, $\mathrm{BaCa}\left(\mathrm{CO}_{3}\right)_{2}$ : an extraordinary example of 'hidden' complex twinning in large single crystals}

\author{
Luca Bindi ${ }^{1 *}$ (D), Andrew C. Roberts ${ }^{2}$ and Cristian Biagioni ${ }^{3}$ \\ ${ }^{1}$ Dipartimento di Scienze della Terra, Università di Firenze, Via G. La Pira 4, I-50121 Firenze, Italy; ${ }^{2}$ Geological Survey of Canada, 601 Booth Street, Ottawa, Ontario \\ K1A 0E8, Canada; and ${ }^{3}$ Dipartimento di Scienze della Terra, Università di Pisa, Via S. Maria 53, I-56126 Pisa, Italy
}

\begin{abstract}
Alstonite, $\mathrm{BaCa}\left(\mathrm{CO}_{3}\right)_{2}$, is a mineral described almost two centuries ago. It is widespread in Nature and forms magnificent $\mathrm{cm}$-sized crystals. Notwithstanding, its crystal structure was still unknown. Here, we report the crystal-structure determination of the mineral and discuss it in relationship to other polymorphs of $\mathrm{BaCa}\left(\mathrm{CO}_{3}\right)_{2}$. Alstonite is trigonal, space group $P 31 \mathrm{~m}$, with unit-cell parameters $a=17.4360(6), c=6.1295(2) \AA, V=1613.80(9) \AA^{3}$ and $Z=12$. The crystal structure was solved and refined to $R_{1}=0.0727$ on the basis of 4515 reflections with $F_{\mathrm{o}}>4 \sigma\left(F_{\mathrm{o}}\right)$ and 195 refined parameters. Alstonite is formed by the alternation, along $\mathrm{c}$, of Ba-dominant and $\mathrm{Ca}$-dominant layers, separated by $\mathrm{CO}_{3}$ groups parallel to $\{0001\}$. The main take-home message is to show that not all structure determinations of minerals/compounds can be solved routinely. Some crystals, even large ones displaying excellent diffraction quality, can be twinned in complex ways, thus making their study a crystallographic challenge.
\end{abstract}

Keywords: alstonite, carbonate, barium, calcium, crystal structure, twinning

(Received 11 June 2020; accepted 25 July 2020; Accepted Manuscript published online: 29 July 2020; Associate Editor: Charles A Geiger)

\section{Introduction}

Alstonite, $\mathrm{BaCa}\left(\mathrm{CO}_{3}\right)_{2}$, is polymorphous with barytocalcite, paralstonite and a recently published synthetic monoclinic phase (Spahr et al., 2019). It was first identified at the Brownley Hill mine near Alston, England, UK in 1834 (Spencer, 1910) and was initially described in the literature by Johnston $(1835,1837)$ and Thomson $(1835,1837)$. The latter author proposed the name 'bromlite' in allusion to an erroneous spelling, 'Bromley', of the mine (Palache et al., 1951). Breithaupt (1841) renamed the mineral 'alstonite' after nearby Alston Moor. Both mineral names had been cited in the literature up until Palache et al. (1951) accepted 'alstonite' as the more expressive, and hence, the more appropriate terminology. Alstonite has been identified in 13 different countries which encompass 25 different mineral localities (see http://www.mindat.org). It is typically found in lowtemperature hydrothermal veins associated with other bariumand calcium-rich phases.

A complete set of mineralogical properties of the mineral is summarised by Roberts (1976 and references therein). Crystallographically, the mineral has been described as orthorhombic (Gossner and Mussgnug, 1930), monoclinic (Dickens, 1971) and triclinic (Sartoril 1975, Roberts, 1976, 1978). Dickens (1971) studied alstonite from the New Brancepath Colliery, Durham, England (Smithsonian specimen USNM 95869) and found a $C$-centred, monoclinic cell with $a=30.163(9)$,

\footnotetext{
*Author for correspondence: Luca Bindi, Email: luca.bindi@unifi.it

Cite this article: Bindi L., Roberts A.C. and Biagioni C. (2020) The crystal structure of alstonite, $\mathrm{BaCa}\left(\mathrm{CO}_{3}\right)_{2}$ : an extraordinary example of 'hidden' complex twinning in large single crystals. Mineralogical Magazine 84, 699-704. https://doi.org/10.1180/ mgm.2020.61
}

$b=17.413(5), c=6.110(1) \AA$ and $\beta=90.10(1)^{\circ}$, with a unit-cell volume 12 times larger than the orthorhombic cell proposed by Gossner and Mussgnug (1930). Zero- and upper-level precession photographs revealed pseudo-hexagonal symmetry normal to (0001). Subsequent Patterson projections confirmed that the $\mathrm{Ba}$ and $\mathrm{Ca}$ atoms were in pseudo-hexagonal layers, according to the sequence $\cdots \mathrm{ABAB} \cdots$, with one layer containing predominantly $\mathrm{Ba}$ atoms and the next layer predominantly $\mathrm{Ca}$ atoms. Additional structural information by Dickens (1971) established the space group as $C 2$. Unfortunately, the structure could only be refined partially as the location of the carbonate groups was uncertain.

A fully resolved crystal structure for alstonite has been unknown up to this point. It was always assumed that the symmetry was lower than hexagonal because of the optical character of the mineral. Numerous studies (Kreutz, 1909; Spencer, 1910; Bellanca, 1941; Rossman and Squires, 1974; Roberts, 1976) have shown that alstonite is biaxial negative with a $2 \mathrm{~V}$ that ranges from 6 to $10^{\circ}$. The other three polymorphs of $\mathrm{BaCa}\left(\mathrm{CO}_{3}\right)_{2}$ have all had their crystal structures determined: barytocalcite (Dickens and Bowen, 1971), paralstonite (Effenberger, 1980) and the recently described synthetic monoclinic form (Spahr et al., 2019). Herein we document the crystal structure of alstonite.

\section{Experimental and structure solution}

Alstonite crystals from four different localities were studied: (1) Fallowfield mine, Northumberland, England, UK (55.00376, -2.09694); (2) Minerva No. 1 mine, Hardin County, Illinois, USA (37.54321, -88.15634); (3) Brownley Hill mine, Nenthead, Alston Moor, Eden, Cumbria, UK (54.79639, -2.34833); and (4) A4119 roadcutting, Llantrisant, Rhondda Cynon Taf, Wales, UK

(C) The Mineralogical Society of Great Britain and Ireland 2020. This is an Open Access article, distributed under the terms of the Creative Commons Attribution licence (http://creativecommons.org/licenses/by/4.0/), which permits unrestricted re-use, distribution, and reproduction in any medium, provided the original work is properly cited. 
$(51.52845,-3.36820)$. Here we report only the results from the first locality (that is the co-type locality of alstonite) because the tested crystal is of excellent diffraction quality with respect to the others.

The intensity data were collected using a Bruker D8 Venture diffractometer equipped with a Photon 100 CMOS and using graphite-monochromatised $\mathrm{MoK} \alpha$ radiation. The detector-tocrystal distance was $50 \mathrm{~mm}$. Data were collected using $\omega$ and $\varphi$ scan modes, with a $0.5^{\circ}$ frame-width and an exposure time of $20 \mathrm{~s}$ per frame. The data were corrected for Lorentz and polarisation factors and absorption using the software package APEX3 (Bruker AXS Inc., 2016).

In expectation of probable crystal twinning, a full diffraction sphere was collected. The diffraction pattern was apparently consistent with hexagonal symmetry [refined cell parameters are $a=17.4360(6) \AA$ and $c=6.1295(2) \AA]$. The statistical tests on the distribution of $|E|$ values $\left(\left|E^{2}-1\right|=0.684\right)$ suggested the structure to be non-centrosymmetric. Although the collected data exhibited very good merging factors according to $\overline{3}\left(R_{\text {int }}=\right.$ $0.077), \overline{3} m 1 \quad\left(R_{\mathrm{int}}=0.081\right), \overline{3} 1 \mathrm{~m}\left(R_{\mathrm{int}}=0.079\right), 6 / m\left(R_{\mathrm{int}}=0.080\right)$, and $6 / \mathrm{mmm}\left(R_{\text {int }}=0.081\right)$ Laue symmetries, the structure was solved initially through direct methods in the triclinic $P 1$ space group because the mineral was always reported as optically biaxial (although with a very low $2 \mathrm{~V}$ angle). After several cycles, an ordered solution with full site occupations was finally determined $\left(R_{1}=0.18\right)$ by carefully removing atoms with low site occupations and/or non-realistic distances with neighbouring atoms and adding significant positions found in the difference Fourier syntheses. Given the very common twinning reported for this mineral, we then took into account the twin law which makes the twin lattice $\left(\mathbf{L}_{\mathrm{T}}\right)$ trigonal (twinning by metric merohedry; Nespolo, 2004) using the program JANA2006 (Petríćck et al., 2006) and the twinning matrices: |100/010/001|, | $|\overline{1} 00 / 0 \overline{1} 0 / 00 \overline{1}|,|100 / \overline{1} 10 / 00 \overline{1}|, \mid \overline{1} 00 /$ $1 \overline{1} 0 / 001|,| \overline{1} 10 / 010 / 001 \mid$ and $|1 \overline{1} 0 / 0 \overline{1} 0 / 00 \overline{1}|$. For details on the averaging of equivalent reflections for twins in JANA, see for instance the appendix in Gaudin et al. (2001). The $R_{1}$ index of the $P 1$ model, refined with SHELXL-97 (Sheldrick, 1997) lowered to 0.093 for $25,532 F_{\mathrm{o}}>4 \sigma\left(F_{\mathrm{o}}\right)$ and 0.095 for all 31,062 data. At this stage, an analysis of the structure with the ADDSYMM routine of the PLATON program (Spek, 2003) revealed the real symmetry to be $P 31 \mathrm{~m}$. The site occupancies of all the metal positions were allowed to vary using different combinations of the scattering curves for neutral $\mathrm{Ba}$ and $\mathrm{Ca}$ atoms (Ibers and Hamilton, 1974) but were found to be occupied by $\mathrm{Ba}$ or $\mathrm{Ca}$ atoms only. At the last stage, which involved refinement of the anisotropic atomic-displacement parameters for all atoms but $\mathrm{C} 4$ and $\mathrm{C} 5$ and no constraints, the residual value converged to $R_{1}=0.073$ for 4515 observed reflections $\left[F_{\mathrm{o}}>4 \sigma\left(F_{\mathrm{o}}\right)\right]$ and 195 parameters and $R_{1}=0.075$ for all 5496 independent reflections.

Table 1 reports further details of the refinement. Atom coordinates and isotropic or equivalent isotropic displacement parameters are given in Table 2 and Table 3 lists the bond distances. The crystallographic information files have been deposited with the Principal Editor of Mineralogical Magazine and are available as Supplementary material (see below).

Although the structural model was optimised in the $P 31 \mathrm{~m}$ space group, we decided to also have a look at the structure using the $C$-centred orthohexagonal cell (with $a \approx 3^{1 / 2} \cdot b$; i.e., $a \approx 30 \AA, b \approx 17.4 \AA$ and $c \approx 6.1 \AA$ ), as reported by previous authors (Gossner and Mussgnug, 1930; Dickens, 1971; Sartori, 1975). The reflection data set was transformed according to the transformation matrix |210/010/001|, again taking into account the twin law that makes the twin lattice hexagonal (i.e. twinning
Table 1. Data and experimental details for the selected alstonite crystal.

\begin{tabular}{|c|c|}
\hline \multicolumn{2}{|l|}{ Crystal data } \\
\hline Formula & $\mathrm{BaCa}\left(\mathrm{CO}_{3}\right)_{2}$ \\
\hline Crystal size (mm) & $0.070 \times 0.085 \times 0.090$ \\
\hline Form & Block \\
\hline Colour & White \\
\hline Crystal system & Trigonal \\
\hline Space group & P31m (\#157) \\
\hline$a(\AA)$ & $17.4360(6)$ \\
\hline$c(\AA)$ & $6.1295(2)$ \\
\hline$V\left(\AA^{3}\right)$ & $1613.80(9)$ \\
\hline $\mathrm{Z}$ & 12 \\
\hline \multicolumn{2}{|l|}{ Data collection } \\
\hline Instrument & Bruker D8 Venture \\
\hline Radiation type & $\operatorname{MoK} \alpha(\lambda=0.71073)$ \\
\hline Temperature (K) & $295(3)$ \\
\hline Detector-to-sample distance $(\mathrm{cm})$ & 5 \\
\hline Number of frames & 1056 \\
\hline Measuring time (s) & 20 \\
\hline Maximum covered $2 \theta\left(^{\circ}\right)$ & 72.96 \\
\hline Absorption correction & multi-scan \\
\hline Collected reflections & 93,518 \\
\hline Unique reflections & 5496 \\
\hline Reflections with $F_{\mathrm{o}}>4 \sigma\left(F_{\mathrm{o}}\right)$ & 4515 \\
\hline$R_{\text {int }}$ & 0.0790 \\
\hline$R_{\sigma}$ & 0.0830 \\
\hline Range of $h, k, l$ & $-14 \leq h \leq 14,0 \leq k \leq 29,-10 \leq l \leq 10$ \\
\hline \multicolumn{2}{|l|}{ Refinement } \\
\hline Refinement & Full-matrix least squares on $F^{2}$ \\
\hline Final $R_{1}\left[F_{\mathrm{o}}>4 \sigma\left(F_{\mathrm{o}}\right)\right]$ & 0.0727 \\
\hline Final $R_{1}$ (all data) & 0.0746 \\
\hline Number refined parameters & 195 \\
\hline GoF & 1.020 \\
\hline$\Delta \rho_{\max }\left(e^{-} \AA^{-3}\right)$ & 8.61 (at $0.63 \AA$ from $\mathrm{Ba} 1$ ) \\
\hline$\Delta \rho_{\min }\left(e^{-} \AA^{-3}\right)$ & -12.26 (at $1.21 \AA$ from Ba1) \\
\hline
\end{tabular}

Table 2. Atoms, fractional atomic coordinates, and isotropic $\left(^{\star}\right)$ or equivalent isotropic displacement parameters $\left(\AA^{2}\right)$ for the selected alstonite crystal.

\begin{tabular}{|c|c|c|c|c|}
\hline Atom & $x / a$ & $y / b$ & $z / c$ & $U_{\text {eq/iso }}$ \\
\hline Ba1 & $0.65993(3)$ & 0 & $0.09661(12)$ & $0.01629(12)$ \\
\hline $\mathrm{Ba} 2$ & $0.83960(5)$ & 0 & $0.5959(3)$ & $0.02957(18)$ \\
\hline Ba3 & $0.50180(3)$ & $0.15658(3)$ & $0.09687(7)$ & $0.01821(11)$ \\
\hline $\mathrm{Ca} 1$ & $0.16090(16)$ & 0 & $0.0978(11)$ & $0.0222(4)$ \\
\hline $\mathrm{Ca} 2$ & $0.32472(17)$ & 0 & $0.5969(5)$ & $0.0271(5)$ \\
\hline $\mathrm{Ca} 3$ & $0.31952(16)$ & $0.49914(9)$ & $0.5962(5)$ & $0.0269(4)$ \\
\hline $\mathrm{C} 1$ & $0.3329(4)$ & $0.1624(5)$ & $0.9268(14)$ & $0.0269(18)$ \\
\hline $\mathrm{C} 2$ & $0.3338(4)$ & $0.1637(4)$ & $0.4351(13)$ & $0.0197(14)$ \\
\hline C3 & 0 & 0 & $0.350(2)$ & $0.017(3)$ \\
\hline C4 & 0 & 0 & $0.836(2)$ & $0.015(3)^{\star}$ \\
\hline C5 & $0.5015(4)$ & 0 & $0.8282(17)$ & $0.0143(16)^{\star}$ \\
\hline C6 & $1 / 3$ & $2 / 3$ & $0.4416(19)$ & $0.028(2)$ \\
\hline $\mathrm{C} 7$ & $1 / 3$ & $2 / 3$ & $0.9177(19)$ & $0.036(3)$ \\
\hline $\mathrm{C} 8$ & $0.5021(4)$ & 0 & $0.358(2)$ & $0.0181(19)$ \\
\hline 01 & $0.4095(5)$ & $0.2372(6)$ & $0.9195(10)$ & $0.0368(15)$ \\
\hline $\mathrm{O} 2$ & $0.3294(4)$ & $0.0839(4)$ & $0.9267(11)$ & $0.0310(12)$ \\
\hline $\mathrm{O} 3$ & $0.2548(5)$ & $0.1619(5)$ & $0.9423(12)$ & $0.0375(15)$ \\
\hline 04 & $0.3396(4)$ & $0.2382(5)$ & $0.4426(14)$ & $0.0371(14)$ \\
\hline 05 & $0.2590(5)$ & $0.0908(5)$ & $0.4254(13)$ & $0.0387(15)$ \\
\hline 06 & $0.4080(5)$ & $0.1596(5)$ & $0.4494(13)$ & $0.0338(13)$ \\
\hline 07 & $0.0707(5)$ & 0 & $0.8472(13)$ & $0.0254(14)$ \\
\hline 08 & $0.0741(5)$ & $0.5779(5)$ & $0.8371(15)$ & $0.0359(16)$ \\
\hline 09 & $0.4288(5)$ & 0 & $0.8427(17)$ & $0.0325(17)$ \\
\hline 010 & $0.6732(5)$ & $0.2604(6)$ & $0.9185(11)$ & $0.0396(16)$ \\
\hline 011 & $0.5981(6)$ & $0.2565(7)$ & $0.4540(14)$ & $0.0480(18)$ \\
\hline 012 & $0.5778(5)$ & $0.0729(5)$ & $0.3511(8)$ & $0.0298(13)$ \\
\hline 013 & $0.4309(5)$ & 0 & $0.3505(11)$ & $0.0348(19)$ \\
\hline 014 & $0.0724(6)$ & 0 & $0.350(2)$ & $0.068(4)$ \\
\hline
\end{tabular}


Table 3. Selected bond-distances (in $\AA$ ) for cations in the selected alstonite crystal.

\begin{tabular}{|c|c|c|c|c|c|}
\hline Ba1-04 & $2.764(8)$ & $\mathrm{Ba} 2-\mathrm{O} 3$ & $2.678(8)$ & Ba3-06 & $2.726(8)$ \\
\hline Ba1-04 & $2.764(8)$ & $\mathrm{Ba} 2-\mathrm{O} 3$ & $2.678(8)$ & Вa3-011 & $2.779(9)$ \\
\hline $\mathrm{Ba} 1-012$ & $2.815(5)$ & $\mathrm{Ba} 2-05$ & $2.758(8)$ & Ba3-O10 & $2.794(7)$ \\
\hline Ba1-012 & $2.815(5)$ & $\mathrm{Ba} 2-\mathrm{O} 5$ & $2.758(8)$ & $\mathrm{Ba3}-\mathrm{O} 2$ & $2.815(7)$ \\
\hline Ba1-01 & $2.833(8)$ & $\mathrm{Ba} 2-014$ & $2.856(8)$ & Вa3-010 & $2.827(8)$ \\
\hline Ba1-01 & $2.833(8)$ & $\mathrm{Ba} 2-014$ & $2.856(8)$ & Ba3-01 & $2.831(7)$ \\
\hline Ba1-08 & $2.844(7)$ & $\mathrm{Ba} 2-\mathrm{O} 4$ & $2.872(7)$ & Вa3-013 & $2.833(4)$ \\
\hline Ba1-08 & $2.844(7)$ & $\mathrm{Ba} 2-\mathrm{O} 4$ & $2.872(7)$ & Ва3-09 & $2.833(6)$ \\
\hline $\mathrm{Ba} 1-\mathrm{O} 3$ & $2.853(7)$ & $\mathrm{Ba} 2-07$ & $2.875(4)$ & Вa3-012 & $2.871(5)$ \\
\hline $\mathrm{Ba} 1-03$ & $2.853(7)$ & $\mathrm{Ba2-07}$ & $2.875(4)$ & Вa3-08 & $2.877(7)$ \\
\hline$<\mathrm{Ba} 1-\mathrm{O}>$ & 2.822 & $<\mathrm{Ba} 2-\mathrm{O}>$ & 2.808 & $<\mathrm{Ba} 3-\mathrm{O}>$ & 2.819 \\
\hline Ca1-014 & $2.184(13)$ & Ca2-09 & $2.359(10)$ & $\mathrm{Ca3}-\mathrm{O} 8$ & $2.339(8)$ \\
\hline Ca1-07 & $2.198(10)$ & $\mathrm{Ca} 2-\mathrm{O} 13$ & $2.389(9)$ & Ca3-O12 & $2.365(7)$ \\
\hline Ca1-O5 & $2.599(10)$ & $\mathrm{Ca} 2-\mathrm{O} 2$ & $2.473(7)$ & Ca3-O10 & $2.466(8)$ \\
\hline Ca1-O5 & $2.599(10)$ & $\mathrm{Ca} 2-\mathrm{O} 2$ & $2.473(7)$ & Сa3-01 & $2.487(8)$ \\
\hline $\mathrm{Ca} 1-\mathrm{O} 3$ & $2.633(8)$ & $\mathrm{Ca} 2-06$ & $2.575(7)$ & Ca3-011 & $2.557(9)$ \\
\hline $\mathrm{Ca} 1-\mathrm{O} 3$ & $2.633(8)$ & $\mathrm{Ca} 2-06$ & $2.575(7)$ & Ca3-06 & $2.585(8)$ \\
\hline $\mathrm{Ca} 1-\mathrm{O} 2$ & $2.752(7)$ & $\mathrm{Ca} 2-\mathrm{O} 5$ & $2.596(8)$ & Ca3-O4 & $2.587(7)$ \\
\hline $\mathrm{Ca} 1-\mathrm{O} 2$ & $2.752(7)$ & Ca2-O5 & $2.596(8)$ & Ca3-011 & $2.616(9)$ \\
\hline$<\mathrm{Ca} 1-\mathrm{O}>$ & 2.544 & $<\mathrm{Ca} 2-\mathrm{O}>$ & 2.505 & $<\mathrm{Ca} 3-\mathrm{O}>$ & 2.500 \\
\hline $\mathrm{C} 1-\mathrm{O} 1$ & $1.321(10)$ & $\mathrm{C} 2-\mathrm{O} 4$ & $1.252(9)$ & C3-O14 & $1.262(10)$ \\
\hline $\mathrm{C} 1-\mathrm{O} 2$ & $1.338(10)$ & $\mathrm{C} 2-\mathrm{O} 5$ & $1.289(9)$ & C3-014 & $1.262(10)$ \\
\hline $\mathrm{C} 1-\mathrm{O} 3$ & $1.360(11)$ & $\mathrm{C} 2-06$ & $1.335(9)$ & C3-014 & $1.262(10)$ \\
\hline$<\mathrm{C} 1-\mathrm{O}>$ & 1.340 & $<\mathrm{C} 2-\mathrm{O}>$ & 1.292 & $<\mathrm{C} 3-\mathrm{O}\rangle$ & 1.262 \\
\hline C4-O7 & $1.235(8)$ & C5-09 & $1.271(10)$ & C6-011 & $1.276(10)$ \\
\hline C4-O7 & $1.235(8)$ & $\mathrm{C} 5-08$ & $1.313(9)$ & C6-011 & $1.276(10)$ \\
\hline $\mathrm{C} 4-07$ & $1.235(8)$ & $\mathrm{C} 5-08$ & $1.313(9)$ & C6-011 & $1.276(10)$ \\
\hline$<C 4-0>$ & 1.235 & $<\mathrm{C} 5-\mathrm{O}>$ & 1.299 & $<\mathrm{C} 6-\mathrm{O}>$ & 1.276 \\
\hline C7-O10 & $1.332(9)$ & C8-013 & $1.242(11)$ & & \\
\hline C7-O10 & $1.332(9)$ & C8-012 & $1.297(8)$ & & \\
\hline $\mathrm{C} 7-010$ & $1.332(9)$ & C8-012 & $1.297(8)$ & & \\
\hline$<C 7-O>$ & 1.332 & $<\mathrm{C} 8-0>$ & 1.279 & & \\
\hline
\end{tabular}

by metric merohedry; Nespolo, 2004 and references therein). A structural model was obtained for both triclinic and monoclinic symmetry, space group $C 1$ and $C m$ (both subgroups of $P 31 \mathrm{~m}$ ). Both the models showed higher $R$ factors than the trigonal P31 m model adopted here.

\section{Crystal structure of alstonite}

\section{Cation coordination}

Fourteen cation and fourteen anion sites occur in the crystal structure of alstonite. Among cation sites, three are occupied by $\mathrm{Ba}$, three by $\mathrm{Ca}$, and eight are $\mathrm{C}$-centred positions. Barium is tenfold coordinated, with average bond distances ranging between 2.808 and $2.822 \AA$, and $\mathrm{Ba}-\mathrm{O}$ distances varying between 2.678 (Ba2-O3) and 2.877 $\AA$ (Ba3-O8). Bond-valence sums (BVS), calculated using the bond parameters of Brese and O'Keeffe (1991), show an overbonding of $\mathrm{Ba}$ atoms, with values ranging between 2.35 and 2.49 valence units (vu) (see Table S1 in the
Supplementary materials). In the two other natural $\mathrm{BaCa}\left(\mathrm{CO}_{3}\right)_{2}$ polymorphs (Table 4), $\mathrm{Ba}$ is ten-fold coordinated in paralstonite, with an average $\langle\mathrm{Ba}-\mathrm{O}\rangle$ distance of $2.812 \AA$ (Effenberger, 1980), and eleven-fold coordinated in barytocalcite, with an average $\langle\mathrm{Ba}-\mathrm{O}\rangle$ distance of $2.909 \AA$ (Dickens and Bowen, 1971). Whereas in paralstonite an oversaturation of $\mathrm{Ba}$ atoms similar to that observed in alstonite can be calculated (2.44 vu, on the basis of the data of Effenberger, 1980), in barytocalcite such an overbonding is smaller, the BVS at the Ba site being 2.16 vu. Such an overbonding observed in alstonite could have different explanations: for instance, the bond character (covalent $v s$. ionic) may vary, and the relationship of Brese and O'Keeffe (1991), using a constant $b$ value, does not account adequately for the different stiffness of the atoms. On the contrary, the observed overbonding can be only partially related to the replacement of Ba by smaller cations (e.g. Sr, as suggested by previous chemical analyses performed on samples from the type locality Kreutz, 1909; Sartori, 1975). Recently, Spahr et al. (2019) described a new synthetic polymorph of $\mathrm{BaCa}\left(\mathrm{CO}_{3}\right)_{2}$, with $\mathrm{Ba}$ and $\mathrm{Ca}$ atoms at a mixed occupied position; the $\left(\mathrm{Ba}_{0.5} \mathrm{Ca}_{0.5}\right) \mathrm{O}_{6}$ polyhedron can be described as a strongly distorted trigonal prism. A six-fold coordination seems to be unusual; for instance in the other known anhydrous barium double carbonate mineral, norsethite, BaMg $\left(\mathrm{CO}_{3}\right)_{2}, \mathrm{Ba}$ is twelve-fold coordinated with an average $<\mathrm{Ba}-\mathrm{O}>$ distance of $2.947 \AA$ (Effenberger and Zemann, 1985), although recent structural investigations suggested a [6+6] coordination for norsethite and its $\mathrm{Mn}$-analogue $\mathrm{BaMn}\left(\mathrm{CO}_{3}\right)_{2}$ (e.g. Effenberger et al., 2014; Pippinger et al., 2014; Wen et al., 2019). In witherite, $\mathrm{BaCO}_{3}, \mathrm{Ba}$ is nine-fold coordinated (e.g. Ye et al., 2012).

Calcium is eight-fold coordinated, with $\langle\mathrm{Ca}-\mathrm{O}>$ distances ranging between 2.500 and $2.544 \AA$; Ca-O distances vary between $2.184(\mathrm{Ca} 1-\mathrm{O} 14)$ and $2.752 \AA(\mathrm{Ca} 1-\mathrm{O} 2)$. This coordination is similar to that occurring in paralstonite, where $\langle\mathrm{Ca}-\mathrm{O}\rangle$ is $2.49 \AA$ (Effenberger, 1980). On the contrary, barytocalcite has seven-fold coordinated $\mathrm{Ca}$, with an average $\langle\mathrm{Ca}-\mathrm{O}\rangle$ distance of $2.388 \AA$ (Dickens and Bowen, 1971).

The eight independent $\mathrm{C}$ sites show the typical flat triangular coordination, with $<\mathrm{C}-\mathrm{O}>$ distances ranging between 1.235 (C4) and $1.340 \AA(\mathrm{C} 1)$. Carbonate groups are parallel to $\{0001\}$, as in paralstonite (Effenberger, 1980). In barytocalcite, on the contrary, $\mathrm{CO}_{3}$ groups are parallel to $\{201\}$ (Dickens and Bowen, 1971).

\section{General features and comparison with paralstonite}

Figure 1 shows the crystal structure of alstonite as seen down $\mathbf{c}$. Two kinds of sequences of $\mathrm{CO}_{3}$ groups and $\mathrm{Ca} / \mathrm{Ba}$ atoms running along a can be distinguished in such a projection. The first one $($ at $y / b=0)$ is $\cdots \mathrm{CO}_{3}-\mathrm{Ca}-\mathrm{Ca}-\mathrm{CO}_{3}-\mathrm{Ba}-\mathrm{Ba}-\mathrm{CO}_{3} \cdots$, whereas at $y / b=\sim 1 / 6,1 / 3, \sim 1 / 2,2 / 3$ and $\sim 5 / 6, \mathrm{Ba}$ and $\mathrm{Ca}$ are neighbours. At $y / b=\sim 1 / 6$ and $\sim 5 / 6$, succeeding pairs of $\mathrm{Ba}$ and $\mathrm{Ca}$ atoms are inverted, whereas in the other layers $(y / b=\sim 1 / 3, \sim 1 / 2$ and $\sim 2 / 3)$, the sequence $\mathrm{Ba}-\mathrm{Ca}$ is maintained. In both cases, slices are mutually

Table 4. Selected anhydrous Ba double carbonates discussed in the text.

\begin{tabular}{|c|c|c|c|c|c|c|c|}
\hline Mineral & Chemical formula & $a(\AA)$ & $b(\AA)$ & $c(\AA)$ & $\beta\left(^{\circ}\right)$ & Space group & Reference \\
\hline Alstonite & $\mathrm{BaCa}\left(\mathrm{CO}_{3}\right)_{2}$ & 17.44 & 17.44 & 6.13 & & P31m & This work \\
\hline Barytocalcite & $\mathrm{BaCa}\left(\mathrm{CO}_{3}\right)_{2}$ & 8.09 & 5.23 & 6.54 & 106.1 & $P 2_{1} / m$ & Dickens and Bowen (1971) \\
\hline Norsethite & $\mathrm{BaMg}\left(\mathrm{CO}_{3}\right)_{2}$ & 5.02 & 5.02 & 16.77 & & $R \overline{3} m$ & Effenberger and Zemann (1985) \\
\hline Paralstonite & $\mathrm{BaCa}\left(\mathrm{CO}_{3}\right)_{2}$ & 8.69 & 8.69 & 6.15 & & P321 & Effenberger (1980) \\
\hline Synthetic & $\mathrm{BaCa}\left(\mathrm{CO}_{3}\right)_{2}$ & 6.68 & 5.10 & 4.19 & 109.3 & $C 2$ & Spahr et al. (2019) \\
\hline
\end{tabular}


(a)
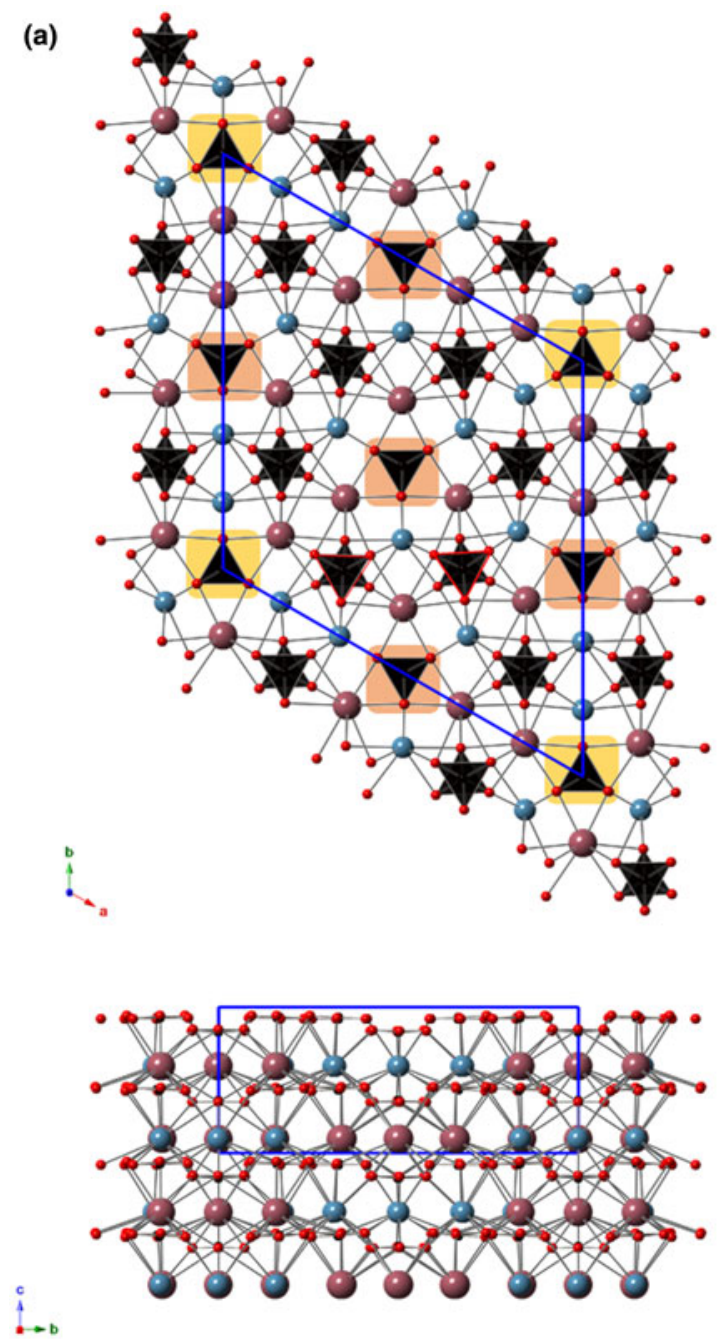

(b)
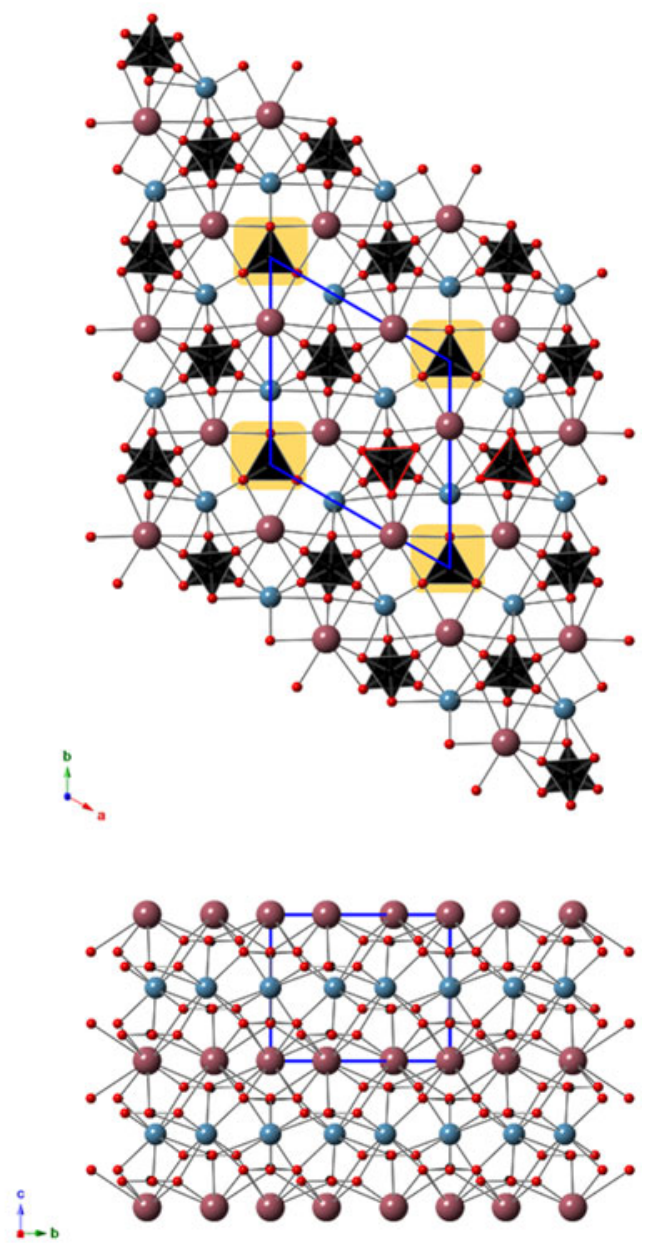

Fig. 1. Crystal structure of alstonite (a), as seen down c (above) and a (below). For the sake of comparison, the same projections for the crystal structure of paraIstonite are shown in (b). Carbonate groups having 'up' and 'down' configurations are highlighted (when not staggered along c) with light yellow and light red boxes, respectively. Selected staggered $\mathrm{CO}_{3}$ groups are outlined with red lines, showing the different 'up' and 'down' configurations. Unit-cells are shown with blue solid lines. Symbols: circles represent $\mathrm{Ba}$ (violet), $\mathrm{Ca}$ (blue) and $\mathrm{O}$ (red) sites. $\mathrm{CO}_{3}$ is shown as black triangles.

shifted. In addition, considering the $\mathrm{O}-\mathrm{O}$ edge of the $\mathrm{CO}_{3}$ triangle perpendicular to the $\mathbf{b}$ direction, two $\mathrm{CO}_{3}$ configurations can be identified: the first one (hereafter called 'up') has the third oxygen in the $+\mathbf{b}$ direction, whereas the other (hereafter called 'down') has the third oxygen in the $-\mathbf{b}$ direction. Rows of $\mathrm{CO}_{3}$ groups with 'up' and 'down' configurations at $y / b=0$ alternate, along $\mathbf{b}$, with rows of $\mathrm{CO}_{3}$ groups in a 'down' configuration at $y / b=1 / 2$. In this configuration, the $\mathrm{C}-\mathrm{O}$ bonds always point towards the smaller $\mathrm{Ca}$ atoms. At $y / b=1 / 6,1 / 3,2 / 3$ and $5 / 6$, staggered $\mathrm{CO}_{3}$ groups occur. These $\mathrm{CO}_{3}$ groups show $\mathrm{C}-\mathrm{O}$ bonds pointing towards different atoms, i.e. three $\mathrm{Ca}$ atoms, two $\mathrm{Ca}$ atoms and one $\mathrm{Ba}$ atom, one $\mathrm{Ca}$ atom and two $\mathrm{Ba}$ atoms, and three $\mathrm{Ba}$ atoms. It is worth noting that these sequences are the result of the projection of two different layers, with the staggered $\mathrm{CO}_{3}$ groups having about the same $z / c$ coordinates showing the same 'up' or 'down' configuration. Indeed, the crystal structure of alstonite can be described as a layered one, formed by the alternation of mixed $(\mathrm{Ca} / \mathrm{Ba})$ layers and $\mathrm{CO}_{3}$ groups parallel to $\{0001\}$. The $\mathrm{Ba} / \mathrm{Ca}$ layer at $z / c \approx 0.10$ is Barich and it is composed by $\mathrm{Ba} 1, \mathrm{Ba} 3$ and $\mathrm{Ca}$ sites; the other layer, at $z / c \approx 0.60$, is Carich and it is composed of $\mathrm{Ba} 2, \mathrm{Ca} 2$ and $\mathrm{Ca} 3$ sites. This is one of the main differences of alstonite with respect to its dimorph paralstonite. Indeed, the latter is characterised by the alternation, along $\mathbf{c}$, of $\mathrm{Ca}$ and $\mathrm{Ba}$ layers, separated by $\mathrm{CO}_{3}$ layers (Fig. 1). In addition, the projection along $\mathbf{c}$ shows the sequence $\cdots \mathrm{Ca}-\mathrm{Ba}-\mathrm{CO}_{3}-\mathrm{Ca}-\mathrm{Ba}-\mathrm{CO}_{3} \cdots$ along $\mathrm{a} ; \mathrm{CO}_{3}$ groups have all the same 'up' configuration for $y / b=0$, whereas they are staggered at $y / b=1 / 3$ and $2 / 3$. In paralstonite, staggered $\mathrm{CO}_{3}$ groups at about the same $z / c$ coordinates display different 'up' and 'down' configurations in a $1: 1$ ratio. The different sequences $\cdots \mathrm{CO}_{3}-(\mathrm{Ba} / \mathrm{Ca}) \cdots$ along a in alstonite and paralstonite are likely to be related to the doubling of the $a$ axis in the former.

\section{Calculated versus observed powder-diffraction pattern}

To verify if the structural model obtained for alstonite matched its powder X-ray diffraction pattern, we also collected powderdiffraction data with a Bruker D8 Venture equipped with a Photon III CCD detector, with graphite-monochromatised $\mathrm{CuK \alpha}$ radiation $(\lambda=1.54138 \AA)$, and with 3 hours of exposure; the detector-to-sample distance was $6 \mathrm{~cm}$. The program APEX3 (Bruker AXS Inc., 2016) was used to convert the measured diffraction rings to a conventional powder-diffraction pattern. The 


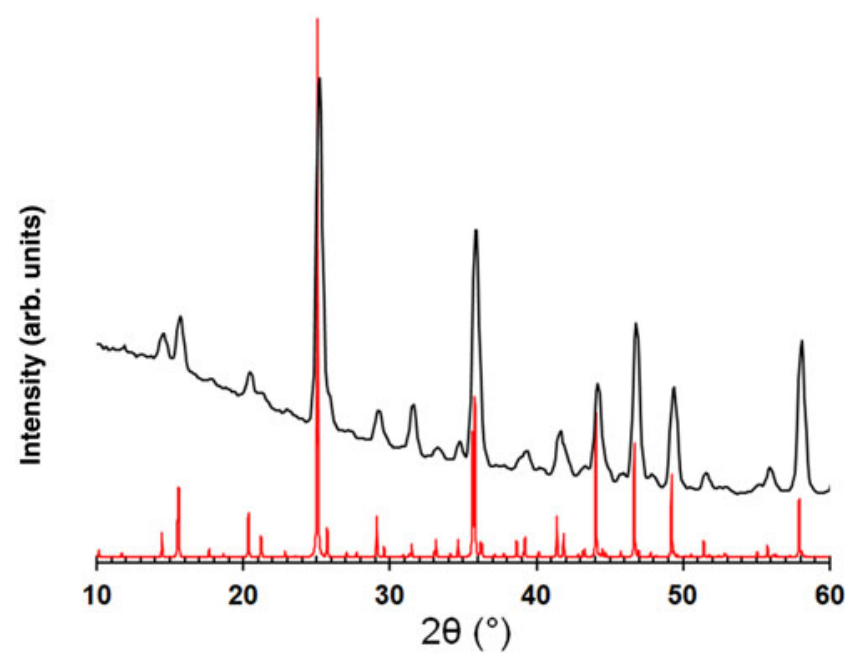

Fig. 2. Calculated (red) vs. observed (black) X-ray powder diffraction data (CuKo radiation) for alstonite.

excellent match between the calculated and observed X-ray powder-diffraction data is visually reported in Fig. 2 and testifies to the validity of the obtained structural model.

\section{Summary and conclusion}

The crystal structure of alstonite has been solved and refined in the space group $P 31 \mathrm{~m}$ and its relationships with paralstonite and barytocalcite are discussed. It is worth noting that the solution of the crystal structure in a space group belonging to the trigonal symmetry, suggested by some morphological features, was initially discouraged by the biaxial optical behaviour of alstonite reported by previous authors. For this reason, these authors (e.g. Dickens, 1971; Sartori, 1975), continued to use a $C$-centred unit cell and persisted in using lower-symmetry models (monoclinic/triclinic) for their structure solutions. However, the present study strongly suggests that the symmetry is actually trigonal and the anomalous optical behaviour could be simulated by minor strain combined with the occurrence of widespread pervasive twinning. This phenomenon is quite common in uniaxial minerals having small 2V angles (e.g. calcite - Turner, 1975; quartz Starkey, 2000).

Notwithstanding its finding in the first half of the 19th Century and its occurrence in well-developed crystals, some up to a $\mathrm{cm}$ in size, the crystal structure of alstonite remained unsolved up to this contribution. Indeed, alstonite is a good example that shows even large crystals having excellent diffraction quality can hide crystallographic pitfalls, such as widespread and complex twinning, thus making the structure solution puzzle a headache.

Supplementary material. To view supplementary material for this article, please visit https://doi.org/10.1180/mgm.2020.61

Acknowledgements. The manuscript took advantage from the review of Herta Effenberger and two anonymous reviewers. Charles Geiger and Stuart Mills are thanked for the efficient handling of the manuscript. Massimo Batoni is acknowledged for providing us with some of the studied specimens of alstonite. The research was funded by MIUR-PRIN2017, project "TEOREM deciphering geological processes using Terrestrial and Extraterrestrial ORE Minerals”, prot. 2017AK8C32 (PI: Luca Bindi).

\section{References}

Bellanca A. (1941) Natura e sintesi dell'Alstonite. Periodico di Mineralogia, 12, 127-141.

Breithaupt J.F.A. (1841) Holoëdrites syntheticus oder Alstonit. Vollständiges Handbuch der Mineralogie, 2, 255-256.

Brese N.E. and O'Keeffe M. (1991) Bond-valence parameters for solids. Acta Crystallographica, B47, 192-197.

Bruker AXS Inc. (2016) APEX3, SAINT and SADABS. Bruker AXS Inc., Madison, Wisconsin, USA.

Dickens B. (1971) Personal communication.

Dickens B. and Bowen J.S. (1971) The crystal structure of $\mathrm{BaCa}\left(\mathrm{CO}_{3}\right)_{2}$ (barytocalcite). Journal of Research of the National Bureau of Standards - A, Physics and Chemistry, 75A, 197-203.

Effenberger H. (1980) Die Kristallstruktur des Minerals Paralstonite, BaCa $\left(\mathrm{CO}_{3}\right)_{2}$. Neues Jahrbuch für Mineralogie, Monatshefte, 1980, 353-363.

Effenberger H. and Zemann J. (1985) Single crystal X-ray investigation of norsethite, $\mathrm{BaMg}\left(\mathrm{CO}_{3}\right)_{2}$ : one more mineral with an aplanar carbonate group. Zeitschrift für Kristallographie, 171, 275-280.

Effenberger H., Pippinger T., Libowitzky E., Lengauer C.L. and Miletich R. (2014) Synthetic norsethite, $\mathrm{BaMg}\left(\mathrm{CO}_{3}\right)_{2}$ : revised crystal structure, thermal behaviour and displacive phase transitions. Mineralogical Magazine, 78, 1589-1612.

Gaudin E., Petř́iček V., Boucher F., Taulelle F. and Evain M. (2001) Structures and phase transitions of the $A_{7} \mathrm{PSe}_{6}(A=\mathrm{Ag}, \mathrm{Cu})$ argyrodite-type ionic conductors. III. $\alpha-\mathrm{Cu}_{7} \mathrm{PSe}_{6}$. Acta Crystallographica, B56, 972-979.

Gossner B. and Mussgnug F. (1930) Über Alstonit und Milarit. Centralblatt für Mineralogie, Geologie und Paläontologie, 220-238.

Ibers J.A. and Hamilton W.C. (editors) (1974) International Tables for X-ray Crystallography, vol. IV. Kynock, Dordrecht, The Netherlands, 366pp.

Johnston J.F.W. (1835) On the dimorphism of baryto-calcite. Philosophical Magazine and Journal of Science, 6, 1-4.

Johnston J.F.W. (1837) LXXVI. On the composition of the right rhombic baryto-calcite, the bicalcareo-carbonate of baryta of Dr. Thomson. Philosophical Magazine and Journal of Science, 10, 373-376.

Kreutz M.S. (1909) O Alstonicie. Uber Alstonite. Bulletin of the Academy of Science, Krakow, 771-802.

Nespolo M. (2004) Twin point groups and the polychromatic symmetry of twins. Zeitschrift für Kristallographie, 219, 57-71.

Palache C., Berman H. and Frondel C. (1951) Volume II: Halides, Nitrates, Borates, Carbonates, Sulfates, Phosphates, Arsenates, Tungstates, Molybdates etc. The System of Mineralogy of James Dwight Dana and Edward Salisbury Dana, Yale University 1837-1892, John Wiley and Sons, Inc., New York, $7^{\text {th }}$ edition, revised and enlarged. Pp. 218-219.

Petrríček V., Dušek M. and Palatinus L. (2006) JANA2006, a Crystallographic Computing System. Institute of Physics, Academy of Sciences of the Czech Republic, Prague, Czech Republic.

Pippinger T., Miletich R., Effenberger H., Hofer G., Lotti P. and Merlini M. (2014) High-pressure polymorphism and structural transitions of norsethite, $\mathrm{BaMg}\left(\mathrm{CO}_{3}\right)_{2}$. Physics and Chemistry of Minerals, 41, 737-755.

Roberts A.C. (1976) A Mineralogical Investigation of Alstonite, $\mathrm{BaCa}\left(\mathrm{CO}_{3}\right)_{2}$. MSc thesis, Department of Geological Sciences, Queen's University, Kingston, Ontario, Canada, 59 pp. [https://doi.org/10.13140/RG.2.1. 4988.8244].

Roberts A.C. (1978) Mineralogical study of an unnamed barium calcium carbonate from the Cave-in-Rock District, Illinois. Geological Survey of Canada Paper, 78-1C, 49-52.

Rossman G.R. and Squires R.L. (1974) The occurrence of alstonite at Cave-in-Rock, Illinois. Mineralogical Record, 5, 266-269.

Sartori F. (1975) New data on alstonite. Lithos, 8, 199-207.

Sheldrick G.M. (1997) SHELXS-97. A program for Automatic Solution of Crystal Structures. University of Göttingen, Germany.

Spahr D., Bayarjargal L., Vinograd V., Luchitskaia R., Milman V. and Winkler B. (2019) A new $\mathrm{BaCa}\left(\mathrm{CO}_{3}\right)_{2}$ polymorph. Acta Crystallographica, B75, 291-300.

Spek A.L. (2003) PLATON, a multipurpose crystallographic tool. Journal of Applied Crystallography, 36, 7-13. 
Spencer L.J. (1910) On the occurrence of alstonite and ullmannite (a species new to Britain) in a barites - witherite vein at the New Brancepath Colliery near Durham. Mineralogical Magazine, 15, 302-311.

Starkey J. (2000) Bi-axial quartz as a stress indicator. Journal of Structural Geology, 22, 383-390.

Thomson T. (1835) Bicalcareocarbonate of barytes. Records of General Science, London, 1, 373.

Thomson T. (1837) IX. On the right rhombic baryto-calcite, with reference to Prof. Johnston's paper in the Phil. Mag. for May 1837. Philosophical Magazine and Journal of Science, 11, 45-48.
Turner F.J. (1975) Biaxial calcite: Occurrence, optics, and associated minor strain phenomena. Contributions to Mineralogy and Petrology, 50, 247-255.

Wen L., Lin L., Yuan Y, Rui L., Zeming L., Xiqiang L., Chaoshuai Z., Shuguang Y., Yong M., Zengsheng L., Yu H. and Heping L. (2019) Crystal structure of norsethite-type $\mathrm{BaMn}\left(\mathrm{CO}_{3}\right)_{2}$ and its pressure-induced transition investigated by Raman spectroscopy. Physics and Chemistry of Minerals, 46, 771-781.

Ye Y., Smyth J.R. and Boni P. (2012) Crystal structure and thermal expansion of aragonite-group carbonates by single-crystal X-ray diffraction. American Mineralogist, 97, 707-712. 